\title{
ELAEOCARPUS SERRATUS L. EXHIBITS POTENTIAL ANALGESIC AND ANTIDIARRHEAL ACTIVITIES IN MICE MODEL
}

\author{
A.A.H. Pinkey', *Z.I. Khan'2, M.A. Taher', M.A. Soma' ${ }^{1}$ \\ 1 - DEPARTMENT OF PHARMACY, STATE UNIVERSITY OF BANGLADESH, DHAKA, BANGLADESH \\ 2 - DEPARTMENT OF HEALTH TECHNOLOGY AND INFORMATICS, THE HONG KONG POLYTECHNIC \\ UNIVERSITY, HONG KONG, CHINA
}

Background. Elaeocarpus serratus L. (Family: Elaeocarpaceae) is a tropical fruit tree, traditionally used in the treatments of poisoning, diarrhea, arthritis, and other diseases.

Objectives. The current study was performed to conduct the analgesic, antidiarrheal, and hypoglycemic activity of E. serratus in mice model using methanolic bark crude extract.

Methods. To assess the peripheral and central analgesic activity, the acetic acid-induced writhing and tail immersion methods were respectively used. The castor-oil mediated antidiarrheal method was used to assess the antidiarrheal activity whereas, the tail tipping technique was conducted to determine the hypoglycemic activity of the plant extract.

Results. In the peripheral analgesic assay, the methanolic bark crude extract of E. serratus significantly inhibits the number of writing $69.77 \%(200 \mathrm{mg} / \mathrm{kg})$ and $73.26 \%(400 \mathrm{mg} / \mathrm{kg})$ respectively $(p<0.05)$ which was strongly comparable with standard NSAID drug diclofenac sodium $75.58 \%(p<0.05)$. Similarly, it shown a significant tail flicking response for 30 minutes, 60 minutes and 90 minutes of central analgesic activity assay. In antidiarrheal activity assay, the E. serratus substantially reduced the number of diarrheal feces $64.26 \%(200 \mathrm{mg} / \mathrm{kg}, p<0.05)$ and $78.57 \%$ (400 mg/kg, $<$ <.05) which was also comparable with the positive control loperamide. The hypoglycemic activity of $E$. serratus extract was not convincing.

Conclusions. Our investigation demonstrated the significant analgesic and antidiarrheal activities of methanolic bark extract of E. serratus (200 and $400 \mathrm{mg} / \mathrm{kg}$ ) in mice model.

KEYWORDS: Elaeocarpus serratus; analgesic activity; antidiarrheal activity; hypoglycemic activity.

\section{Introduction}

Medicinal plants or natural drugs are traditionally and historically used around the globe by human beings for curing various ailments. The plant-derived natural drugs are widely accepted to all due to their diverse pharmacological activities, reduced toxicity, cost-effective, availability for drug discovery, and application to the chemical biology $[1,2]$. Although, the incessant investigation is being carried out to screen potential pharmacological activities of natural products but the numbers are very limited considering all medicinal plants distributed throughout the world [3]. So far, a considerable number of experimental research have been reported the use of natural products as an antioxidant agent, blood glucose-lowering agent, antimicrobial agent, central nervous system (CNS) stimulating agent, anti-diarrheal

*Corresponding author: Md Zahirul Islam Khan, Department of Health Technology and Informatics, The Hong Kong Polytechnic University, 100077, Hong Kong, China.

E-mail: zahir.islamkhan@connect.polyu.hk agent, anti-helminthic agent, anti-inflammatory agent, and anti-cancer agent [4]. By considering the previous studies, we explored the pharmacological activities of Elaeocarpus serratus L. (E. serratus) in a number of biological uses.

E. serratus (English name: Rosary nut, Ceylon olive, Bengali name: Jalpai) belongs to the family Elaeocarpaceae, a tropical fruit tree grown up to 18 meters tall, distributed in evergreen forests, and sometimes also cultivated for its edible fruit and medicinal applications $[5,6]$. It is mostly found in the Indian subcontinent regions including India, Bangladesh, Pakistan, Sri Lanka and Nepal. However, it is also found in Indo-China regions including, Myanmar, Indonesia, Thailand and Malaysia [5]. The E. serratus is a plant having both nutritional and medicinal values. For instance, the GC-MS analysis revealed that the plant contains numerous compounds including fatty acid, alcohol, aldehyde, hydrocarbons and alkenes which are biologically active [7]. In 
addition, the leaf of E. Serratus contains alkaloids, flavonoids, and glycosides (eg. anthraquinone) [7]. Moreover, a list of bioactive compounds also contained in E. serratus such as myricitrin, mearnsetin 3-O- $\beta$-D-glucoside, mearnsitrin, and tamarixetin 3-O-a-L-rhamnopyranoside where, myricitrin is an established potential antioxidant [8]. Historically, leaves of $E$. serratus extracts are used for the treatments of arthritis and various poisoning [9]. Equally, appetite, diarrhea, dysentery and other neuro-motors related diseases are commonly treated with fruits or fruit extracts $[6,10]$. Moreover, the previous studies also reported that the leaf, bark and fruit of $E$. serratus have antimicrobial and antifungal activities [11, 12]. For all we know, there is no scientific report conducted on analgesic, hypoglycemic, and anti-diarrheal properties of E. serratus yet. Therefore, our main objective was to assess the analgesic, hypoglycemic, and antidiarrheal activity of methanolic bark crude extract of $E$. serratus in mice model.

\section{Methods}

Collection and extraction of plant

In February 2018, the bark of E. Serratus was acquired from Chandpur, Bangladesh. The collection of bark samples was verified by Bangladesh National Herbarium (BDNH), Dhaka, Bangladesh. An herbarium specimen number (DACB-31155) was provided and preserved for their further reference. The barks were cleaned and cut into small pieces to accelerate the drying process. Then the sundried fragments were crushed to a fine powder. About $400 \mathrm{~g}$ of powder was put in a flat bottom amber sterile glass container and socked with $1.5 \mathrm{~L}$ methanol for two weeks. Continuous shaking and stirring were maintained over time. Afterward, the entire mixture was filtered with cotton and repeated second filtration with Whatman filter paper (Bibby RE200, Sterilin Ltd., UK). The filtrate was then kept for a week allowed to concentrate with a rotary evaporator at $45^{\circ} \mathrm{C}$ and $50 \mathrm{rpm}$. Finally, $28.0 \mathrm{~g}$ (yield 5.63\%) of a black gummy substance was obtained referring to crude methanol extract of $E$. serratus bark. The extract was aliquot into $2 \mathrm{ml}$ centrifuge tubes and stored at $4^{\circ} \mathrm{C}$ for further uses.

\section{Experimental animals}

To conduct the experiments, the Swiss albino mice $(20-24 \mathrm{gm})$ were brought from International Centre for Diarrheal Disease Research, Bangladesh (ICDDR). The animals had a typical environmental condition (at 24.0 $\pm 1^{\circ} \mathrm{C}$ and $55-65 \%$ relative humidity), in cages with 12 hours of dark and light cycles. Until starting of the experiments, the animals were housed to embrace the local laboratory conditions for a week. In each bioassay, the animals were selected randomly and sub-divided into four separated groups consist of positive control (PC) group, negative control (NC) group and two experimental groups receiving $E$. serratus crude extract at doses of $200 \mathrm{mg} / \mathrm{kg}$ body weight (b.w.) (ES-I) and $400 \mathrm{mg} / \mathrm{kg}$ b.w. (ES-II). Mice were remarkably observed for a week to monitor any suffering or distress and fasted overnight prior to the experiments. The animal experiments were conducted according to the Ethics Committee of State University of Bangladesh (SUB), Dhaka, Bangladesh.

Drug treatments and chemical reagents

Diclofenac sodium, glibenclamide, and loperamide hydrochloride were purchased from Beximco Pharmaceuticals Ltd (Bangladesh). Phenobarbitone sodium and morphine sulphate were supplied by Incepta Pharmaceuticals Ltd (Bangladesh), and Beacon Pharmaceuticals Ltd (Bangladesh). Tween 80, normal saline $(0.9 \% \mathrm{NaCl})$ and castor oil were kindly given by BDH Chemicals Ltd (United Kingdom). The remaining chemicals and reagents were purchased from Sigma-Aldrich (Munich, Germany).

\section{Peripheral analgesic activity}

The acetic acid-mediated writhing method by Kaushik, D., et al. 2012 was copied to assess the peripheral analgesic activity of the $E$. serratus crude extract [13]. The intraperitoneal acetic acid injection was given to all mice with a view to exhort the abdominal pain followed by writhing in mice. The potentialities of the test samples were measured by calculating their competency in the reduction of writhing numbers. Test group (ES-I and ES-II) were orally administered, containing the doses of 200- and $400 \mathrm{mg} / \mathrm{kg}$ of body weight (b.w.), respectively. Whereas, the NC group orally received $1 \%$ tween 80 in saline and the PC group orally received diclofenac sodium at $50 \mathrm{mg} / \mathrm{kg}$ dose [14]. To induce writhing in mice, $1 \% \mathrm{v} / \mathrm{v}$ acetic acid was given intraperitoneally to all mice $(10 \mathrm{ml} / \mathrm{kg}$ b.w.) followed by a resting period of 40 minutes after test samples administration. The writhing cases were carefully observed and documented for 10 minutes after giving $10 \mathrm{mi}-$ nutes resting period. The acetic acid-induced pain reduction was calculated by using the following equation: 
$\%$ of writhing inhibition $=\frac{(\text { Mean writhing of control-Mean writhing of test }) \times 100 \%}{\text { Mean writhing of control }}$

Central analgesic activity

Pizziketti et al., 1985 described the tail-flick method was implemented to assess the central analgesic activity of $E$. serratus crude extract in mice [15]. In this method, the mice were orally given a different dose of drugs and E. serratus, and the tips of the mice tails were submerged in a constant radiant heat source (hot water bath at $55 \pm 0.5^{\circ} \mathrm{C}$ ). The reaction time (mice tail deflects from the heating source) of each mouse was recorded using a stopwatch. To prevent the damage of tail, we maintained a cut off period of 15 seconds. Similar to the peripheral analgesic study, the NC group orally received $1 \%$ tween- 80 in saline, and the PC group was subcutaneously injected with morphine (2 mg/kg b.w.) [16]. The ES-I and ES-II were prescribed orally to the test groups of mice. The tail-flick reaction was counted and recorded in 0 minutes, 30 minutes, 60 minutes, and 90 minutes after administration of the test samples. The following equation was used to measure the pain inhibition percentage (PIP).

$$
P I P=\frac{(\text { Mean latency of treatment }- \text { Mean latency of control) } \times 100 \%}{\text { Mean latency of control }}
$$

\section{Hypoglycemic activity}

The tail tipping technique according to the method described by Durschlag et al., 1996 was repeated to assess the hypoglycemic activity of test samples in mice model [17]. Here, the NC group was treated with $1 \%$ tween- $80(0.1 \mathrm{ml} / 10$ mg b.w.), and PC group treated with glibenclamide ( $5 \mathrm{mg} / \mathrm{kg}$ b.w.) whereas, GroupIII and Group-IV were treated with ES-I and ES-II respectively. All treatments were applied orally [14]. To accelerate the blood sugar level of mice, a $10 \%$ glucose solution was orally given to all mice after an hour resting period at dose $2 \mathrm{~g} / \mathrm{kg}$ b.w. Blood is withdrawn from the tail tip and blood sugar was measured and recorded by using a glucometer (Bioland G-423 S) in 0 minutes, 30 minutes, 60 minutes, 120 minutes, and 180 minutes respectively.

\section{Antidiarrheal activity}

The antidiarrheal activity of $E$. serratus crude extract was determined by the method described by Shaoba and Thomas [18], where forceful diarrhea is induced by orally administrating $1.0 \mathrm{ml}$ of castor oil to all mice. Similar to other studies, various oral treatments were applied to the mice such as NC group received $1 \%$ tween- 80 in saline, PC group received loperamide hydrochloride $(50 \mathrm{mg} / \mathrm{kg}$ b.w.) and the remaining two groups were given ES-I and ES-II respectively [19]. All groups of mice were housed in individual cages with a blotting paper placed beforehand. The number of diarrheal feces were recorded for each mice over four hours of the experiment. The percentage of diarrheal prohibition was accounted for using the following formula:

$$
\text { Percentage inhibition }=\frac{\text { Mean defecation of control-Mean defecation of test sample or standard }}{\text { Mean writhing of control }} \times 100 \%
$$

\section{Statistical analysis}

The values are represented here are set of mean \pm standard error of mean $(\mathrm{M} \pm \mathrm{SEM})$. All the calculation was performed using student t-test or one way ANOVA followed by Dunnett's test to determine the statistically significant differences between the groups. A p-value < 0.05 was considered statistically significant.

\section{Results}

The peripheral analgesic activity of $E$. serratus crude extract is demonstrated in Table 1. A significant reductions of abdominal muscle contractions caused by the administration of $0.1 \mathrm{ml}$ acetic acid were exhibited in both expe- rimental groups where ES-II showed higher writhing inhibition and was close to the PC group. Our results indicated that the E. serratus bark crude extracts significantly inhibit the number of writhing $69.77 \%$ and $73.26 \%$ at dose 200 and $400 \mathrm{mg} / \mathrm{kg}$ b.w. gradually whilst diclofenac sodium displayed $75.58 \%$ writhing inhibition.

Values are represented here as mean of \pm SEM. NC=1\% tween 80 in water, $P C=$ diclofenac sodium, ES-I: E. serratus crude extract-I, ES-II: E. serratus crude extract-II. M1-4=mice 1 to 4 respectively. $(n=4, * p<0.01)$

The result of the tail-flick method to assess the central analgesic activity of $E$. serratus are 
Table 1. Peripheral analgesic activity of $E$. serratus bark crude extract

\begin{tabular}{|l|c|c|c|c|c|c|}
\hline \multirow{2}{*}{ Mice group } & \multicolumn{4}{|c|}{ Writhing count (sec) } & \multirow{2}{*}{$\begin{array}{c}\text { Number of writhing } \\
\text { (Mean } \pm \text { SEM) }\end{array}$} & $\begin{array}{c}\text { \% Inhibition } \\
\text { of writhing }\end{array}$ \\
\cline { 2 - 5 } & M-1 & M-2 M-3 & M-3 & M-4 & $21.50 \pm 0.65^{*}$ & - \\
\hline NC & 20 & 21 & 23 & 22 & $5.25 \pm 0.25^{*}$ & 75.58 \\
\hline EC & 5 & 6 & 5 & 5 & $6.50 \pm 0.29^{*}$ & 69.77 \\
\hline ES-II & 7 & 6 & 6 & 7 & $5.75 \pm 0.25^{*}$ & 73.26 \\
\hline
\end{tabular}

shown in table 2. Both experimental groups ES-I and ES-II increased the response time by $37.32 \%$ and $53.72 \%$ respectively in the initial 30 minutes of the experiment, whereas PC morphine increased by $85.24 \%$. In addition, $82.76 \%$ (200 mg/kg b.w.), 98.94\% (400 mg/kg b.w.) tail flicking response were recorded in 60 minute, and 149.27\% (200 mg/kg b.w.) and $179.46 \%$ (400 mg/kg b.w.) were recorded in 90 minutes of the experiments. The whole experiment followed a dose-dependent tail flicking response over the time.

Values are represented here as mean of \pm SEM. NC=1\% tween 80 in water, $\mathrm{PC}=$ morphine sulfate, ES-I: E. serratus crude extract-I, and ES-II: E. serratus crude extract-II. $(n=4, * p<0.01)$

The bark crude extract of $E$. serratus not displayed any significant blood glucose-lowering activity at doses 200 and $400-\mathrm{mg} / \mathrm{kg}$ b.w. However, the percent of blood sugar reducing activity was found to be followed in a dosedependent manner. The results shown in table 3 indicated that the highest glucose lowering activity was displayed at dose $400 \mathrm{mg} / \mathrm{kg}$ b.w. relative to ES-I groups.

Values are represented here as mean of \pm SEM. NC=1\% tween 80 in water, PC=glibenclamide, ES-I: E. serratus crude extract-I, and ES-II: E. serratus crude extract-II. $\left(n=4,{ }^{*} p<0.01\right)$

The remarkable antidiarrheal activities were displayed by ES-I and ES-II in mice. The potential antidiarrheal activity of the $E$. serratus crude extract is shown in table 4. The ES-I and ES-II substantially reduced the number of castor oilincited diarrheal feces by $64.29 \%$ and $78.57 \%$ compared to the NC. The highest diarrheal reduction was shown by $\mathrm{PC}$ group.

Values are represented here as mean of \pm SEM. NC=1\% tween 80 in water, PC=loperamide hydrochloride, ES-I: E. serratus crude extract-I,

Table 2. Central analgesic activity of E. serratus bark crude extract

\begin{tabular}{|l|c|c|c|c|c|c|}
\hline \multirow{2}{*}{$\begin{array}{c}\text { Mice } \\
\text { group }\end{array}$} & \multicolumn{2}{|c|}{30 minutes of assay } & \multicolumn{2}{c|}{60 minutes of assay } & \multicolumn{2}{c|}{90 minutes of assay } \\
\cline { 2 - 7 } & $\mathrm{M} \pm \mathrm{SEM}$ & $\%$ of elongation & $\mathrm{M} \pm \mathrm{SEM}$ & $\%$ of elongation & $\mathrm{M} \pm \mathrm{SEM}$ & $\%$ of elongation \\
\hline $\mathrm{NC}$ & $3.49 \pm 0.32^{*}$ & - & $3.55 \pm 0.08^{*}$ & - & $3.60 \pm 0.20^{*}$ & - \\
\hline PC & $6.47 \pm 0.11 *$ & 85.24 & $9.57 \pm 0.25^{*}$ & 169.39 & $13.19 \pm 0.35^{*}$ & 266.07 \\
\hline ES-I & $4.79 \pm 0.34^{*}$ & 37.32 & $6.49 \pm 0.35^{*}$ & 82.76 & $8.98 \pm 0.25^{*}$ & 149.27 \\
\hline ES-II & $5.37 \pm 0.32 *$ & 53.72 & $7.07 \pm 0.39 *$ & 98.94 & $10.07 \pm 0.42 *$ & 179.46 \\
\hline
\end{tabular}

Table 3. Hypoglycemic activity of $E$. serratus bark crude extract

\begin{tabular}{|c|c|c|c|c|c|c|}
\hline \multirow{2}{*}{$\begin{array}{c}\text { Mice } \\
\text { group }\end{array}$} & \multicolumn{2}{|c|}{60 minutes of assay } & \multicolumn{2}{c|}{120 minutes of assay } & \multicolumn{2}{c|}{180 minutes of assay } \\
\cline { 2 - 7 } & $\begin{array}{c}\mathrm{M} \pm \mathrm{SEM} \\
(\mathrm{mmol} / \mathrm{L})\end{array}$ & $\%$ Reduction & $\begin{array}{c}\mathrm{M} \pm \mathrm{SEM} \\
(\mathrm{mmol} / \mathrm{L})\end{array}$ & $\%$ Reduction & $\begin{array}{c}\mathrm{M} \pm \mathrm{SEM} \\
(\mathrm{mmol} / \mathrm{L})\end{array}$ & \% Reduction \\
\hline NC & $12.60 \pm 0.87$ & & $8.55 \pm 0.31$ & & $4.45 \pm 0.34$ & \\
\hline PC & $5.63 \pm 0.39$ & 55.36 & $4.23 \pm 0.57$ & 50.58 & $2.6 \pm 0.17$ & 41.57 \\
\hline ES-I & $10.18 \pm 0.61$ & 19.25 & $7.05 \pm 0.39$ & 17.54 & $3.95 \pm 0.23$ & 11.24 \\
\hline ES-II & $10.08 \pm 0.93$ & 20.04 & $6.85 \pm 0.38$ & 19.88 & $3.75 \pm 0.19$ & 15.73 \\
\hline
\end{tabular}

Table 4. Antidiarrhoeal activity of $E$. serratus bark crude extract

\begin{tabular}{|l|c|c|c|}
\hline \multicolumn{1}{|c|}{ Mice group } & Dose & $\begin{array}{c}\text { Number of diarrheal } \\
\text { feces (Mean } \pm \text { SEM) }\end{array}$ & \% Reduction of diarrhea \\
\hline NC & $10 \mathrm{ml} / \mathrm{kg} \mathrm{b.w.}$ & $3.5 \pm 0.58^{*}$ & - \\
\hline PC & $50 \mathrm{mg} / \mathrm{kg} \mathrm{b.w.}$ & $0.5 \pm 0.48^{*}$ & 85.71 \\
\hline ES-I & $200 \mathrm{mg} / \mathrm{kg} \mathrm{b.w.}$ & $1.25 \pm 0.85^{*}$ & 64.29 \\
\hline ES-II & $400 \mathrm{mg} / \mathrm{kg} \mathrm{b.w.}$ & $0.75 \pm 0.71 *$ & 78.57 \\
\hline
\end{tabular}


and ES-II: E. serratus crude extract-II. ( $n=4$, $\left.{ }^{*} p<0.01\right)$

\section{Discussion}

Acetic acid may trigger the writhing reflex in experimental animals where visceral pain is generated through activation of pain receptors on the visceral surface and extreme secretion of histamine, prostaglandins, bradykinin and serotonin [20]. In the experimental animals, acetic acid induces visceral pain which is commonly treated with NSAID drugs or chemicals, such as phenyl quine (prostaglandin E2 inhibitor). In addition, the level of analgesia is measured by calculating the percent reduction of abdominal contraction by drugs or crude extract after intraperitoneal administration of acetic acid to mice. In this study, E. serratus extracts significantly reduced the sum of abdominal contraction of $69.77 \%$ and $73.26 \%$ by ES-I and ES-II compared to NC. Importantly, the results of peripheral analgesic activity by ES-I and ES-II were almost equal to the diclofenac treatment. Therefore, by considering our results, we assumed that $E$. serratus extract may be inhibited the synthesis or release of endogenous substances in mice to act its potential peripheral analgesic activity. However, further research may need to explore the exact mechanisms.

In the central analgesic assay, the relative promotion of tail-flicking response (in percent) was obtained from $E$. serratus extract in a dose and time-dependent manner. Although, the responses from $E$. serratus crude extracts were a bit of lower than the PC-morphine however, higher dose might be shown an equals or higher potentiality like morphine. Pizziketti, et al., 1985 demonstrated that the tail flicking response is mostly generated from spinal reflex caused by radiant heat source however it may involve higher neuronal complex signals. In general, the pain is centrally originated via a number of complex signaling such as opiate, dopaminergic, noradrenergic and serotonergic nervous systems [15]. Our results described that E. serratus displayed a significantly higher level of pain threshold activity at 200 and $400 \mathrm{mg} / \mathrm{kg}$ b.w. respectively in mice model. The core mechanisms may be associated with the receptor-bind inhibition of pain-related nervous system or through peripheral mechanisms involved prohibited prostaglandins, leukotrienes, and other endogenous substances release and synthesis which are key mediators of pain [21]. Our results might be followed the same mechanisms to exhibit the potential analgesic activity in mice model.

Our bark crude extract of $E$. serratus shown lack of blood glucose lowering activity. Notwithstanding, a considerable number of studies have concluded that plant extracts exhibit potential anti-hyperglycemic activity by accelerating or regenerating $\beta$ cells or promoting the secretion of insulin $[22,23]$. The hypoglycemic activity by the natural product may also associated with excessive insulin secretion from $\beta$ cells or trigger the peripheral glucose consumption, or promote insulin-mediated blood sugar absorbing mechanisms [22-24].

Apart from this, the statistical evaluation revealed that both doses of $E$. serratus showed a significant dose-dependent anti-diarrheal activity in mice. The ricinoleic fatty acid or 12-hydroxy-9-cis-octadecenoic acid is an active metabolite of castor oil. This metabolic fatty acid enhanced peristaltic activity in the small intestine to trigger the permeability of mucosal electrolytes thus resulting diarrhea $[25,26]$. Furthermore, ricinoleic fatty acid enhanced mucosal irritation and inflammation which contribute to the excessive endogenous prostaglandin secretion. Moreover, in castor oilinduced diarrheal mechanisms it involved a cascade of signaling including, intestinal $\mathrm{Na}^{+} /$ $\mathrm{K}^{+}$-ATPase inhibition, adenylate cyclase activation or promotion CAMP-mediated plateletactivating factor secretion $[25,27]$.

In summary, the plant $E$. serratus contained several flavonoids, anthraquinone glycosides, fatty acid, alcohol, aldehyde, hydrocarbons alkaloids, terpenoids, and steroids. $[7,8,28]$. The presence of glycosides, steroids, and flavonoids which exhibited potential analgesic, hypoglycemic and antidiarrheal activities in many plants [29-31]. In the present study, we concluded that $E$. serratus extract may contain a variety of bioactive phytochemicals. After successful isolation and characterization of phytochemicals, it might be used as an analgesic, and as an antidiarrheal agent.

\section{Conclusion}

The bark extract of $E$. serratus exhibited potential peripheral and central analgesic activity, very mild hypoglycemic activity but effective antidiarrhoeal activity in mice model. Therefore, further investigations are needed to isolate and characterization of bioactivite molecules present in this plant. Further research may open a new therapeutic agents in the treatments of various diseases. 


\section{Acknowledgement}

All the authors acknowledge that all the experiments were ethically approved by the Department of Pharmacy, State University of Bangladesh. No additional fund was provided for this study. We thankful to Dr. Azam for assistance with the English improvements.

Conflict of Interests

Authors declare no conflict of interest.

\section{Funding}

No funding was received for this study.

\section{Author's Contributions}

Asma Aul Husna Pinkey, Mohammad Abdullah Taher - conceptualization, methodology; Asma Aul Husna Pinkey, investigation, data curation, formal analysis, writing - original draft; Zahirul Islam Khan - data curation, formal analysis, writing - reviewing and editing; Mahfuza Afroz Soma - writing - reviewing and editing.

\title{
ПРЕКЛІНІЧНІ ДОСЛІДЖЕННЯ ЗНЕБОЛЮЮЧОЇ ТА ПРОТИПРОНОСНОЇ ДІЇ ELAEOCARPUS SERRATUS L. HA MИШАХ
}

\author{
A.A.H. Pinkey', *Z.I. Khan'2, M.A. Taher'1, M.A. Soma' \\ 1 - DEPARTMENT OF PHARMACY, STATE UNIVERSITY OF BANGLADESH, DHAKA, BANGLADESH \\ 2 - DEPARTMENT OF HEALTH TECHNOLOGY AND INFORMATICS, THE HONG KONG POLYTECHNIC UNIVERSITY,
}

HONG KONG, CHINA

Вступ. Elaeocarpus serratus L. (родина Elaeocarpaceae) - тропічне плодове дерево, фрукти, кора та інші частини якого традиційно використовуються при лікуванні отруєнь, діареї, артриту та інших захворювань.

Мета - дослідити фармакологічну активність (знеболювальну, протидіарейну та гіпоглікемічну дію) сухого метанольного екстракту кори E. serratus на мишах.

Методи. Для експериментальної оцінки центрального та периферичного компонентів у механізмі знеболювальної дії екстракту використовували метод оцінки больової реакції, що викликається хімічним подразненням - метод «оцтовокислих корчів", та метод теплового подразнення, суть якого полягає в зануренні хвоста миші у гарячу воду $\left(55 \pm 0.5^{\circ} \mathrm{C}\right)$. Для оцінки протипроносної активності використовували модель діареї, викликаної введенням рициновою олією, для визначення гіпоглікемічної активності екстракту використали метод Durschlag et al., 1996, забір крові проводили иляхом надрізів хвоста.

Результати. Встановлено, що застосування сухого метанольного екстракту кори E. serratus достовірно зменшує частоту розвитку корчів на 69,77\% (200 мг/кг) ma 73,26\% (400 мг/кг) відповідно $(p<0,05)$, що досягає рівня активності стандартного НПзП диклофенаку натрію, який зменшує показник на $75,58 \%$ (р<0.05). Такі ж результати щодо частоти реакції хвоста піддослідних тварин протягом 30, 60 та 90 хвилин - показника чентральної знеболюючої активності екстракту. Щодо протипроносної активності, то E. Serratus зменшував частоту діареї на 64.26\% (200 мг/к2, p<0,05) ma 78,57\% (400 мг/к2, p<0,05), що також досягало також жефективності, які і г групі позитивного контролю з лоперамідом. Щодо гіпоглікемічної активності екстракту E. serratus - отримані нами результати були непереконливими.

Висновок. Наше дослідження продемонструвало значну знеболювальну та протидіарейну активність сухого метанольного екстракту кори E. serratus (200 та 400 мг/кг) на мишах.

КЛЮЧОВІ СЛОВА: Elaeocarpus serratus; знеболювальна активність; протипроносна активність; гіпоглікемічна активність

Information about the authors

Asma Aul Husna Pinkey, graduate student, State University of Bangladesh, Dhaka, Bangladesh

ORCID 0000-0002-6851-269X, e-mail: pinkeykhanam88@gmail.com

Md Zahirul Islam Khan, full-time PhD student, The Hong Kong Polytechnic University, Hong Kong, China

ORCID 0000-0001-7048-2613, e-mail: zahir.islamkhan@connect.polyu.hk

Mohammad Abdullah Taher, lecturer and coordinator, State University of Bangladesh, Dhaka, Bangladesh

ORCID 0000-0002-0701-470X, e-mail: taher@sub.edu.bd

Mahfuza Afroz Soma, lecturer and Student Counselor, State University of Bangladesh, Dhaka, Bangladesh

ORCID 0000-0003-2903-8822, e-mail: soma@sub.edu.bd 


\section{References}

1. Saleh-e-In MM, Sultana N, Hossain MN, Hasan S, Islam MR. Pharmacological effects of the phytochemicals of Anethum sowa L. root extracts. BMC Complement Altern Med. 2016 Dec;16(1):464.

DOI: https://doi.org/10.1186/s12906-016-1438-9

2. Khan MF, Khan ZI, Uddin MR, Rahman MS, Rashid MA. In vivo hypoglycemic and alloxan induced antidiabetic activity of Xeromphis uliginosa Retz. Afr J Pharm Pharmacol. 2015;9(11):363-6.

DOI: https://doi.org/10.5897/AJPP2015.4293

3. Al-Snafi AE. Encyclopedia of the constituents and pharmacological effects of Iraqi medicinal plants. Rigi Publication; 2015.

4. Van Wyk B-E, Wink M. Medicinal plants of the world. CABI; 2018. 0000

DOI: https://doi.org/10.1079/9781786393258.

5. Baruah PS, Deka K, Lahkar L, Sarma B, Borthakur SK, Tanti B. Habitat distribution modelling and reinforcement of Elaeocarpus serratus L. - A threatened tree species of Assam, India for improvement of its conservation status. Acta Ecologica Sinica. 2019;39(1):42-9. 06.002

DOI: https://doi.org/10.1016/j.chnaes.2018.

6. de Lima FF, Breda CA, Cardoso CAL, Duarte MCT, Sanjinez-Argandoña EJ. Evaluation of nutritional composition, bioactive compounds and antimicrobial activity of Elaeocarpus serratus fruit extract. Afr J Food Sci. 2019;13(1):30-7.

DOI: https://doi.org/10.5897/AJFS2018.1760

7. Geetha D, Rajeswari M, Jayashree I. Chemical profiling of Elaeocarpus serratus L. by GC-MS. Asian Pac J Trop Biomed. 2013;3(12):985-7. 60190-2

DOI: https://doi.org/10.1016/S2221-1691(13)

8. Jayasinghe L, Amarasinghe NR, Arundathie BS, Rupasinghe GK, Jayatilake NAN, Fujimoto Y. Antioxidant flavonol glycosides from Elaeocarpus serratus and Filicium decipiens. Nat Prod Res. 2012; 26(8):717-21. 1514

DOI: https://doi.org/10.1080/14786419.2010.55

9. Geetha D, Jayashree I, Rajeswari M. In vitro anti-arthritic activity of Elaeocarpus serratus Linn. (Elaeocarpaceae). Int J Pharm Sci Res. 2015;6(6):2649.

10. Hardainiyan S, Nandy BC, Kumar K. Elaeocarpus ganitrus (Rudraksha): A reservoir plant with their pharmacological effects. Int J Pharm Sci Rev Res. 2015;34:55-64.

11. Jayashree I, Geetha D, Rajeswari M. Evaluation of antimicrobial potential of Elaeocarpus serratus $L$. Int J Pharm Sci Res. 2014;5(8):3467-72.

12. Sneha S, Sharath R, Aishwarya K, Samrat K, Vasundhara M, Radhika B. Screening of the antioxidant, antibacterial and cytotoxic activities of the methanolic extracts of Elaeocarpus ganitrus and Elaeocarpus serratus. Int Res J Innov Eng. 2015; 1:1-11.

13. Kaushik D, Kumar A, Kaushik P, Rana AC. Analgesic and anti-inflammatory activity of Pinus roxburghii Sarg. Adv Pharmacol Sci. 2012;2012:245431. doi: $10.1155 / 2012 / 245431$

DOI: https://doi.org/10.1155/2012/245431

14. Sharmin T, Rahman MS, Mohammadi $\mathrm{H}$. Investigation of biological activities of the flowers of Lagerstroemia speciosa, the Jarul flower of Bangladesh. BMC Complement Altern Med. 2018;18(1): 231.

DOI: https://doi.org/10.1186/s12906-018-2286-6 15. Pizziketti R, Pressman N, Geller E, Cowan A, Adler M. Rat cold water tail-flick: a novel analgesic test that distinguishes opioid agonists from mixed agonist-antagonists. Eur J Pharmacol. 1985;119(1-2): 23-9.

DOI: https://doi.org/10.1016/0014-2999(85) 90317-6

16. Adeyemi OO, Okpo SO, Ogunti OO. Analgesic and anti-inflammatory effects of the aqueous extract of leaves of Persea americana Mill (Lauraceae). Fitoterapia. 2002;73(5):375-80. 00118-1

DOI: https://doi.org/10.1016/S0367-326X(02)

17. Dürschlag $M$, Würbel $H$, Stauffacher $M$, von Holst D. Repeated blood collection in the laboratory mouse by tail incision-modification of an old technique. Physiol Behav. 1996;60(6):1565-8.

DOI: https://doi.org/10.1016/S0031-9384(96) 00307-1

18. Shoba FG, Thomas M. Study of antidiarrhoeal activity of four medicinal plants in castor-oil induced diarrhoea. J Ethnopharmacol. 2001;76(1):73-6.

DOI: https://doi.org/10.1016/S0378-8741(00) 00379-2

19. Pal A, Al Mahmud Z, Akter N, Islam S, Bachar SC. Evaluation of Antinociceptive, Antidiarrheal and Antimicrobial Activities of Leaf Extracts of Clerodendrum indicum. Phcog J. 2012;4(30):41-6.

DOI: https://doi.org/10.5530/pj.2012.30.8

20. Padi SSV, Kulkarni SK. Minocycline prevents the development of neuropathic pain, but not acute pain: Possible anti-inflammatory and antioxidant mechanisms. Eur J Pharmacol. 2008;601(1):79-87. 10.018

DOI: https://doi.org/10.1016/j.ejphar.2008.

21. Shojaii A, Motaghinejad M, Norouzi S, Motevalian M. Evaluation of anti-inflammatory and analgesic activity of the extract and fractions of Astragalus hamosus in animal models. Iran J Pharm Res. 2015;14(1):263-9.

22. Hannan J, Marenah L, Ali L, Rokeya B, Flatt P, Abdel-Wahab Y. Ocimum sanctum leaf extracts stimulate insulin secretion from perfused pancreas, isolated islets and clonal pancreatic $\beta$-cells. J Endocrinol. 2006;189(1):127-36.

DOI: https://doi.org/10.1677/joe.1.06615

23. Gray AM, Flatt PR. Insulin-releasing and insulin-like activity of the traditional anti-diabetic plant Coriandrum sativum (coriander). Br J Nutr. 1999;81(3):203-9.

DOI: https://doi.org/10.1017/ S0007114599000392 
24. Ota A, Ulrih NP. An overview of herbal products and secondary metabolites used for management of type two diabetes. Front Pharmacol. 2017;8:436.

DOI: https://doi.org/10.3389/fphar.2017.00436

25. Iwao I, Terada Y. On the mechanism of diarrhea due to castor oil. Jpn J Pharmacol. 1962; 12(2):137-45.

DOI: https://doi.org/10.1254/jjp.12.137

26. Bright-Asare $P$, Binder HJ. Stimulation of colonic secretion of water and electrolytes by hydroxy fatty acids. Gastroenterology. 1973;64(1):81-8. 80094-0

DOI: https://doi.org/10.1016/S0016-5085(73)

27. Tiruppathi C, Balasubramanian K, Hill P, Mathan V. Faecal free fatty acids in tropical sprue and their possible role in the production of diarrhoea by inhibition of ATPases. Gut. 1983;24(4):300-5.

DOI: https://doi.org/10.1136/gut.24.4.300
28. Jayashree I, Geetha D, Rajeswari M. Evaluation of antimicrobial potential of Elaeocarpus serratus $\mathrm{L}$. Int J Pharm Sci and Res. 2014;5(8):3467.

29. Zhang D-W, Cheng Y, Wang N-L, Zhang J-C, Yang M-S, Yao X-S. Effects of total flavonoids and flavonol glycosides from Epimedium koreanum Nakai on the proliferation and differentiation of primary osteoblasts. Phytomedicine. 2008;15(1-2):55-61.

DOI: https://doi.org/10.1016/j.phymed.2007. 04.002

30. Kajaria DK, Gangwar M, Sharma AK, Nath G, Tripathi Y, Tripathi J, et al. Comparative evaluation of phenol and flavonoid content of polyherbal drugs. Pharmacologyonline. 2011;3:1365-73.

31. Arif M, Fareed S. Pharmacognostical studies and evaluation of total phenolic and flavonoid contents of traditionally utilized fruits of Solanum torvum Sw. Indian J Nat Prod Resour. 2011;2(2):218-24.

Received 21 Sep 2020; revised 11 Nov 2020; accepted 14 Dec 2020.

This is open access article distributed under the Creative Commons Attribution License, which permits unrestricted use, distribution, and reproduction in any medium, provided the original work is properly cited. 